УДК 338.439.5:338.484:339.132:636.033 (477)

JEL Classification: Q 13

DOI: https://doi.org/10.32317/2221-1055.201907021

О.А. КОЗАК, кандидат економічних наук, старший науковий співробітник

О.Ю. ГРИЩЕНКО

\title{
Особливості формування попиту та пропозиції на ринку яловичини
}

\begin{abstract}
Mета статmі - здійснити комплексний аналіз особливостей формування попиту та пропозицї на ринку яловичини України.

Методика дослідження. У процесі дослідження використано методи: абстрактно-логічний - для формулювання висновків; монографічний - при деталізації функціонування ринку яловичини; порівняльного аналізу і рядів динаміки - для порівняння показників та виявлення тенденцій їх зміни у часі; статистичний - при проведенні аналізу попиту і пропозиції на ринку яловичини; графічний - для виявлення й ілюстрації тенденцій досліджуваних економічних явищ; економікоматематичні методи - при визначенні економічних показників, що впливають на попит та пропозицію яловичини.

Результати дослідження. Проаналізовано сучасний стан ринку яловичини в Україні та визначено основні проблеми його розвитку з позиції як виробника, так і споживача. 3'ясовано фактори, які найбільшою мірою впливають на формування попиту та пропозиції яловичини.

Елементи наукової новизни. Набули подальшого розвитку аналітичні оцінки і визначення впливу основних факторів на формування попиту та пропозиції на ринку яловичини України.

Практична значущість. Результати дослідження будуть корисними для виробників та споживачів яловичини, а також зацікавлених сторін продовольчого ланцюга цієї продукції. Обгрунтовані висновки можуть слугувати орієнтиром для урядовців при розробці довгострокової політики розвитку ринку яловичини в Україні. Табл.: 2 . Рис.: 7. Бібліогр.: 16.
\end{abstract}

Ключові слова: попит; пропозиція; ринок яловичини; м'ясне скотарство; експорт; імпорт; Україна.

Козак Ольга Анатоліївна - кандидат економічних наук, старший науковий співробітник, провідний науковий співробітник відділу економіки аграрного виробництва та міжнародної інтеграції, Національний науковий центр «ннститут аграрної економіки» (м. Київ, вул. Героїв Оборони, 10)

E-mail: olya.kozak@gmail.com

ORCID iD https://orcid.org/0000-0002-2197-3456

Грищенко Олена Юріївна - завідувач сектору інформаційного забезпечення досліджень, Національний науковий центр «нститут аграрної економіки» (м. Київ, вул. Героїв Оборони, 10)

E-mail: lena@iae.kiev.ua

Постановка проблеми. Яловичина належить до одних із найбільш цінних і популярних у світі видів м'яса та посідає у рейтингу корисності третє місце, поступаючись перед олениною та кролятиною. Виробництво i споживання яловичини у світі постійно зростає, а ряд причин вказують на продовження цих тенденцій. Основна 3 них загальносвітова зміна структури раціону харчування населення у напрямі збільшення частки м'яса («м'ясна революція»), у тому числі яловичини, особливо в країнах, що розвиваються. Цьому сприяла глобальна урбанізація, що призвела до зростання доходів, а відповідно до зміни структури раціону

๑) О.А. Козак, О.Ю. Грищенко, 2019 в бік збільшення споживання білка, зокрема тваринного походження; суттєвий ріст числа людей з надмірною вагою, що зумовило використання яловичини у більшості дієт при правильному харчуванні; популяризація споживання яловичини, в тому числі у непереробленому вигляді, ґрунтуючись на висновках наукових досліджень, та підсиленою роботою маркетингових компаній; збільшення чисельності населення, що харчуються поза домом; особливе значення яловичини для осіб, що потерпають від багатьох захворювань або тих, хто переніс операції, після крововтрати тощо. До того ж, чисельність населення на планеті постійно зростає. 
Україна в дореформений період традиційно виробляла значні обсяги яловичини порівняно з іншими видами м'яса, які перероблялися переважно у м'ясні вироби, а рівень споживання на кінець 80-х років минулого століття становив 30 кг на особу в рік. Кризові явища в процесі переорієнтації на ринкову економіку, а потім і ряд інших економічних криз, мали особливо негативні наслідки як для виробника, так і для споживача яловичини. Тривалий період деструктивні явища інерційно накопичувалися та призвели в кінцевому підсумку до настільки деформованої структури ринку згаданої продукції, що ставиться під сумнів взагалі його існування як самостійного сегмента. Втім, як завжди, «втрутився» зовнішній ринок із жорсткими правилами і вимогами, а тому постала необхідність переформатування існуючого ринку яловичини та приведення його до загальновизнаних світових стандартів функціонування, де діють об'єктивні економічні закони.

Аналіз останніх досліджень і публікацій. Стосовно основних аспектів розвитку виробництва яловичини в Україні та ринку продукції скотарства відомі праці багатьох науковців, зокрема: М.В. Гладія, П.Т. Саблука, Н.Г. Копитець [10], Ю.О. Лупенка, В.Я. Месель-Веселяка [6], М.В. Місюка [5], В.М. Микитюка [4], А. Панкратова [7], І.В. Свиноуса [11], О.М. Шпичака [12], А. Ярмака [8] та інших. Проте, враховуючи стан ринку яловичини, а також його важливість і перспективність у зв'язку з посиленням євроінтеграційних процесів та зростанням попиту на українську яловичину з країн, де існує дефіцит цієї продукції, виникає потреба проведення глибоких досліджень щодо особливостей формування попиту та пропозиції на ринку яловичини та визначення факторів, що їх зумовлюють.

Мета статті - здійснити комплексний аналіз особливостей формування попиту та пропозиції на ринку яловичини України.

Виклад основних результатів дослідження. Яловичина в Україні належить до соціально значущих продуктів харчування, а розвиток скотарства сприяє вирішенню продовольчої безпеки країни. Трансформаційний період в Україні особливо негативно позначився на розвитку галузі скотарства, яка тривалий час знаходиться в економічній кризі. Учені одностайні в тому, що серед усіх галузей вона зазнала найбільш руйнів- них деструктивних змін [10, с. 214], [5, с. 61], [4, с. 227]. Аналіз динаміки виробництва яловичини з 1960 р. по теперішній час свідчить, що пікових для України обсягів було досягнуто у 1990 р., за вироблених майже 2 млн тонн, з яких понад 90\% - у підприємствах суспільного сектору. Для порівняння: такі обсяги у 1990 р. виробляли Франція, Німеччина, Австралія. У структурі виробництва різних видів м'яса на яловичину в той період припадало 45,6\%, свинину 36,2 , птицю - 16,3\%. Вироблена яловичина надходила на переробні підприємства, де 3 неї виготовляли різноманітні м'ясні продукти. У 1990 р. на душу населення вироблялося 84 кг м'яса, в тому числі 38,3 кг яловичини, споживання у перерахунку на м'ясо знаходилося на рівні відповідно 68,1 та 30 кг. Такі показники значною мірою були зумовлені сприятливими природно-кліматичними умовами України: наявністю сільськогосподарських земель, природних пасовищ, виробництвом значних обсягів сільськогосподарських культур, які слугували основою харчового раціону великої рогатої худоби та іншими факторами. За майже 30 років виробництво яловичини зменшилося до 358,9 тис. тонн у 2018 р., або у 5,5 раза, а поголів'я худоби - до 3332,9 тис. голів, або у 8 разів (найнижчий показник за всю сучасну історію України). Скорочення було спричинено сукупністю факторів, зокрема проблемами з реалізацією м'яса на переробні підприємства (відмова їх від яловичини), ціновою політикою (диспаритет цін перехідного періоду), високою збитковістю виробництва та відповідно скороченням поголів'я, низькою культурою споживання яловичини в країні, особливо в непереробленому вигляді (звідси пасивність приватного сектору щодо розвитку галузі та іî конкуренції з підсобним свинарством і птахівництвом), низькою купівельною спроможністю населення, значними втратами галузі у першу фазу реформ, які не можуть бути швидко відтворені у зв'язку з особливостями ведення м'ясного скотарства тощо. За цей період у світі відбувалися зворотні процеси. Так, виробництво яловичини збільшилося від 53,0 млн тонн у 1990 р. до 66,3 млн тонн у 2017 р., або на 25,1\% та на 6,1\% за останні 10 років. Зростання виробництва у світі за цей період зумовлено його ростом у країнах, що розвиваються (країни Близького Сходу та Північної Африки). 
Разом із зменшенням обсягів виробництва яловичини в Україні зазнала змін структура виробництва м'яса за видами: у 2008 р. $41,7 \%$ у ній становила курятина, 31,0 - свинина, 25,2\% - яловичина, тоді як у 2018 р. ці показники відповідно змінилися на 53,5\%, 29,8 і 15,2\%. До того ж, скорочення виробництва яловичини у сільськогосподарських підприємствах ніяк не компенсувалося особистими селянськими господарствами, що подолавши у 2003 р. свій історичний макси- мум виробництва 484,2 тис. тонн почали стабільно його скорочувати (рис. 1). Утім частка особистих селянських господарств у загальних обсягах виробництва залишалася високою, досягнувши у 2018 р. 75,6\%. Загалом протягом реформ галузь із промислово розвиненої перейшла практично у численні селянські подвір'я 1 , де неможливо відстежити ні фактичне поголів'я, ні обсяги виробництва, ні схеми реалізації продукції, ні ціни на неї та ін.

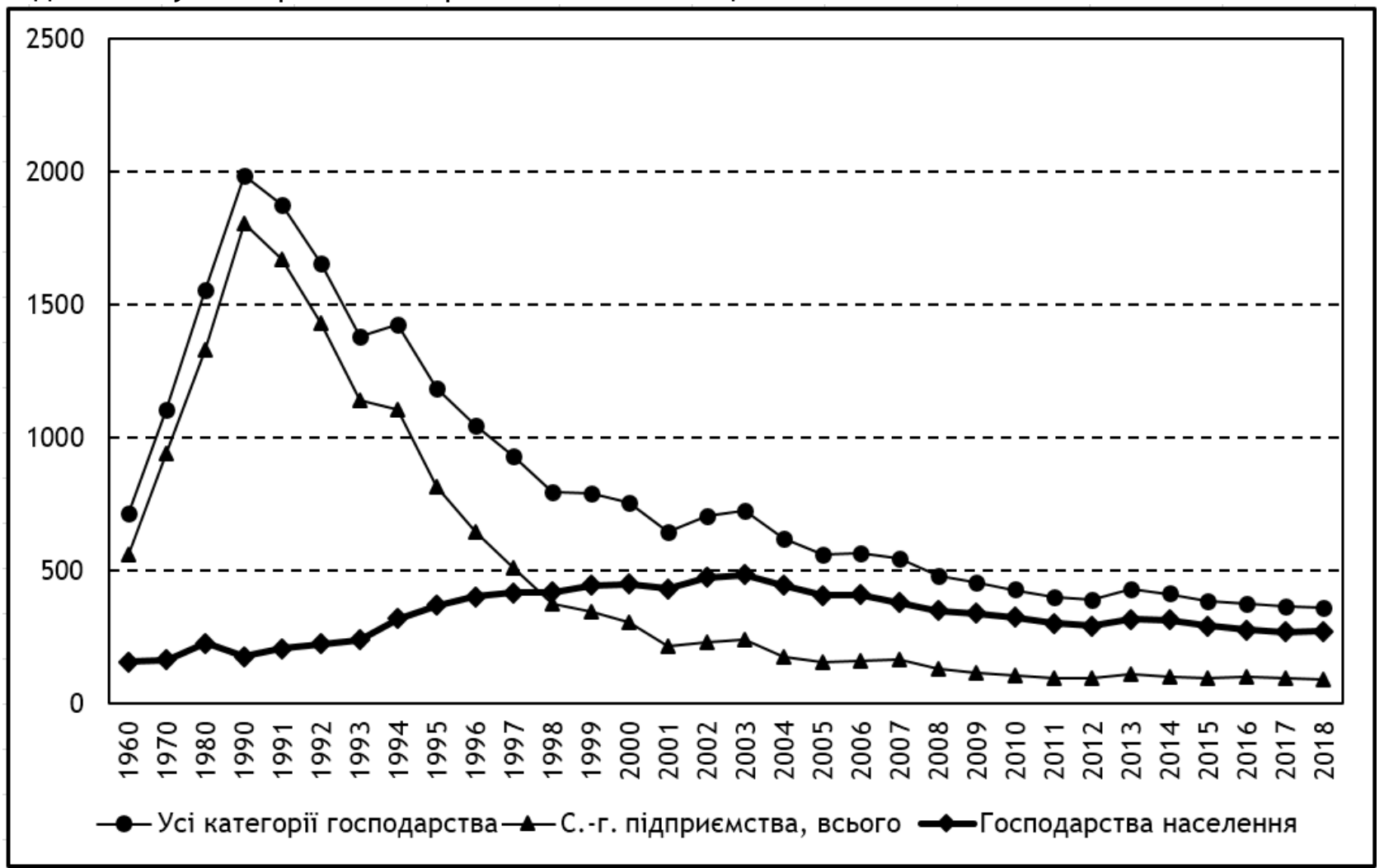

Рис. 1. Динаміка виробництва яловичини і телятини (у забійній масі) за категоріями господарств, 1960-2018 рр.

Джерело: Складено за даними Державної служби статистики України.

Організація виробництва яловичини у сільськогосподарських підприємствах і господарствах населення суттєво різниться. Так, чисельність сільськогосподарських підприємства, що утримували ВРХ, у 2018 р. була 2296 господарств, особистих селянських - близько $1 \mathrm{млн.} \mathrm{Середній} \mathrm{розмір} \mathrm{госпо-}$ дарства - відповідно 496 та 2,46 голів худоби. Існують розбіжності й у напрямах реалізації. Якщо сільськогосподарські підприємства 60,3\% своєї сировини реалізують на переробні підприємства, то особисті селянські господарства - лише 5,4\% (табл. 1). У цілому поза організованим ринком, який передбачає реєстрацію руху продукції, знаходиться понад 80\% виробленої яловичини, або 468,3 тис. тонн. При цьому переробні під- приємства працюють переважно з сировиною сільськогосподарських підприємств, частка яких у структурі надходжень яловичини досягає 71,9\%.

Тіньовий характер функціонування ринку яловичини можна спостерігати, розглянувши реалізацію на забій худоби у головах та середню масу однієї голови, а також надходження їх на переробні підприємства (табл. 2).

\footnotetext{
1 За оцінками експертів, що базуються в тому числі на даних вибіркового обстеження Державної служби статистики України, чисельність господарств, які утримували поголів'я ВРХ у 2018 р. склала близько 1 млн одиниць.
} 
1. Канали реалізації виробленої яловичини різними категоріями господарств

\begin{tabular}{|c|c|c|c|c|c|c|}
\hline \multirow[t]{2}{*}{ Показник } & \multicolumn{2}{|c|}{$\begin{array}{c}\text { Сільськогосподарські } \\
\text { підприємства }\end{array}$} & \multicolumn{2}{|c|}{$\begin{array}{c}\text { Господарства } \\
\text { населення }\end{array}$} & \multicolumn{2}{|c|}{$\begin{array}{l}\text { Усі категорії } \\
\text { господарств }\end{array}$} \\
\hline & 2008 p. & 2018 p. & 2008 p. & 2018 p. & 2008 p. & $2018 \mathrm{p}$. \\
\hline $\begin{array}{l}\text { Вироблено яловичини, } \\
\text { тис. тонн (у живій масі) }\end{array}$ & 199,3 & 145,2 & 506,3 & 419,5 & 705,6 & 564,7 \\
\hline $\begin{array}{l}\text { Реалізовано яловичини, } \\
\text { тис. тонн (у живій масі) }\end{array}$ & 221,6 & 148,5 & 591,6 & 461,4 & 813,2 & 609,9 \\
\hline $\begin{array}{l}\text { У т.ч. переробним } \\
\text { підприємствам }\end{array}$ & 142,477 & 89,5 & 85,1 & 24,7 & 227,6 & 114,2 \\
\hline $\begin{array}{l}\text { На ринку, через власні } \\
\text { магазини, ларьки, палатки }\end{array}$ & 27,0 & 8,9 & - & - & 27,0 & 8,9 \\
\hline $\begin{array}{l}\text { Власне спожите та } \\
\text { подароване родичам }\end{array}$ & - & & 16,2 & 18,5 & 16,2 & 18,5 \\
\hline Інша реалізація & 52,1 & 50,1 & 490,3 & 418,2 & 542,4 & 468,3 \\
\hline
\end{tabular}

Джерело: Складено та розраховано за даними Державної служби статистики України.

\section{2. Чисельність великої рогатої худоби, реалізованої на забій, та жива маса однієї} голови (за категоріями господарств)

\begin{tabular}{|c|c|c|c|c|c|c|}
\hline \multirow[t]{2}{*}{ Показник } & \multicolumn{2}{|c|}{$\begin{array}{l}\text { Усі категорії } \\
\text { господарств }\end{array}$} & \multicolumn{2}{|c|}{$\begin{array}{c}\text { Сільськогоспо- } \\
\text { дарські підприємства }\end{array}$} & \multicolumn{2}{|c|}{$\begin{array}{c}\text { Господарства } \\
\text { населення }\end{array}$} \\
\hline & 2008 p. & 2018 p. & 2008 p. & 2018 p. & 2008 p. & $2018 \mathrm{p}$. \\
\hline $\begin{array}{l}\text { Чисельність ВРХ, } \\
\text { реалізованих на забій у } \\
\text { живій масі, тис. голів }\end{array}$ & 3255,6 & 2145,9 & 664,9 & 394,4 & 2590,7 & 1751,5 \\
\hline $\begin{array}{l}\text { Середня маса однієї } \\
\text { голови, реалізованої } \\
\text { на забій, кг }\end{array}$ & 250 & 284 & 333 & 376 & 228 & 264 \\
\hline $\begin{array}{l}\text { Чисельність ВРХ, } \\
\text { куплених переробними } \\
\text { підприємствами у живій } \\
\text { масі, тис. голів }\end{array}$ & 769,2 & 245,9 & 329,1 & 196,1 & 397,9 & 49,8 \\
\hline $\begin{array}{l}\text { Середня маса однієї } \\
\text { голови, реалізованої } \\
\text { на переробні підприємст- } \\
\text { ва, кг }\end{array}$ & 411 & 464 & 403 & 456 & 418 & 497 \\
\hline $\begin{array}{l}\text { Частка реалізованої ВРX, } \\
\text { що надійшла на переробні } \\
\text { підприємства, \% }\end{array}$ & 23,6 & 11,5 & 49,5 & 49,7 & 15,4 & 2,8 \\
\hline
\end{tabular}

Джерело: Складено та розраховано за даними Державної служби статистики України.

Дані таблиці свідчать, що на переробку надходить лише $11,5 \%$ реалізованих тварин, у тому числі сільськогосподарські підприємства реалізують $49,7 \%$ від усіх проданих тварин, особисті селянські господарств - до 3\%. Останні на переробку поставляють переважно корів $(64,5 \%$ серед усього поголів'я, що надійшло від ОСГ) та бичків старше 2 років $(16,3 \%)$.

Серед особливостей галузі - м'ясне скотарство, як самостійна галузь, в Україні розвинена слабо. У 2018 р. сільськогосподарські підприємства утримували 56,9 тис. голів м'ясної худоби, або 5\% від загального поголів'я ВРX. У країнах з високим рівнем споживання яловичини цей показник перевищує 75\% (Австралія, Аргентина, Бразилія,
Уругвай, Канада), у Франції, Іспанії, Ірландії, США - від 25 до 75\%, у Німеччині, Чехії, Угорщині - до 25\% [3]. Чисельність господарств, які спеціалізуються на виробництві м'яса яловичини в Україні (без молочного напряму), у 2018 р. становила близько 50 (великих і середніх), або 2,2\% від усіх господарств, які утримували ВРХ. Решта - це молочно-товарні ферми, де виробництво яловичини фактично $€$ побічним продуктом при виробництві молока. Звідси, основне джерело отримання яловичини переробними підприємствами - відгодівельний молодняк зі шлейфу молочних стад (переважно бички) сільськогосподарських підприємств. При цьому м'ясна худоба реалізується за цінами молочної, що не дає поштовху для 
розвитку м'ясного скотарства як окремої галузі. Щодо господарств населення, то їх стадо представлене молочною великою рогатою худобою. Реалізацію формують вибракувані корови та «молочні» бички (переважно віком до року), які скуповуються посередниками для постачання як на переробні підприємства, так і забою їх з подаль- шим продажем на роздрібному продовольчому ринку [11, с. 83-84].

Ефективність виробництва яловичини характеризується хронічною збитковістю (починаючи з 1995 р.), за винятком 2017-го, коли в організаційно-економічному устрої галузі нічого не змінилося, проте ціни на яловичину зросли, і це відразу позначилося на ефективності (рис. 2).

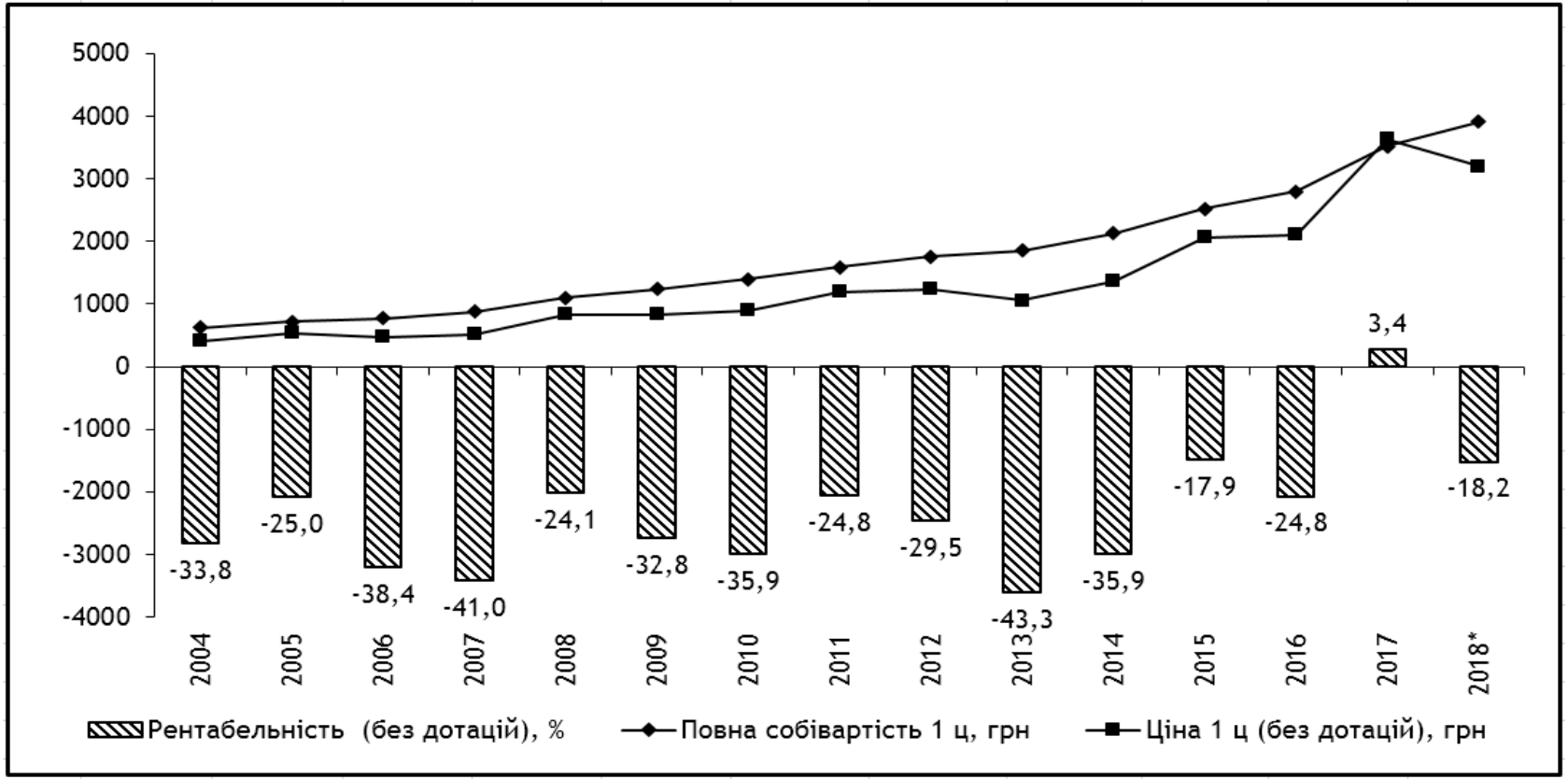

\section{Рис. 2. Економічна ефективність виробництва яловичини в сільськогосподарських підприємствах}

Джерело: 2004-2017 рр. - складено за даними Державної служби статистики України;“ 2018 р. - за даними [6, с. 41].

Експерти пояснюють зростання цін різними причинами: спалахом африканської чуми, яка призвела до підвищення цін на свинину та, відповідно, на інші види м'яса; скороченням поголів'я ВРX, що створює дефіцит продукції, підвищенням попиту, в тому числі зовнішнього; закриттям російського ринку, який оживив внутрішній [13]. На нашу думку, зростання цін було викликано не внутрішнім попитом, який, на жаль, знижується, не спадом поголів'я, яке й до 2017 р. постійно скорочувалося, не африканською чумою чи російським ринком, а залежністю українських цін від світових. Тому зростання світових цін внаслідок обмеженої пропозиції на спотових ринках і активного попиту на ринках країн Азії відразу позначилося всередині країни. Подальше зростання світових цін впливатиме на внутрішній ринок i, за умови відсутності росту доходів, призводитиме до ще меншого споживання яловичини.

Зазначимо, що споживання яловичини в Україні постійно зменшується. Так, у 2017 р. це 7,5 кг на душу населення у рік, що вже тривалий період нижче встановленої межі раціональної норми - 16 кг на одну особу в рік (для працездатного населення), передбаченої Постановою Кабінету Міністрів України від 11 жовтня 2016 р. № 780 «ро затвердження наборів продуктів харчування, наборів непродовольчих товарів та наборів послуг для основних соціальних і демографічних груп населення» [9] (рис. 3). Довідково: до 2000 р. в Україні діяла рекомендована норма радянських часів, що становила близько 30 кг яловичини в рік. Офіційні дані статистики щодо споживання яловичини на одну особу в рік буде оприлюднено 31 липня 2019 р., проте експерти м'ясного ринку передбачають зменшення порівняно з попереднім роком на 7,3\% [1]. Разом із тим, за даними ФАО, різких змін у споживанні найближчим часом не відбудеться [8, с. 27], тобто швидше за все споживання буде ще нижчим або ж, за оптимістичного сценарію, залишатиметься на тому самому рівні. 


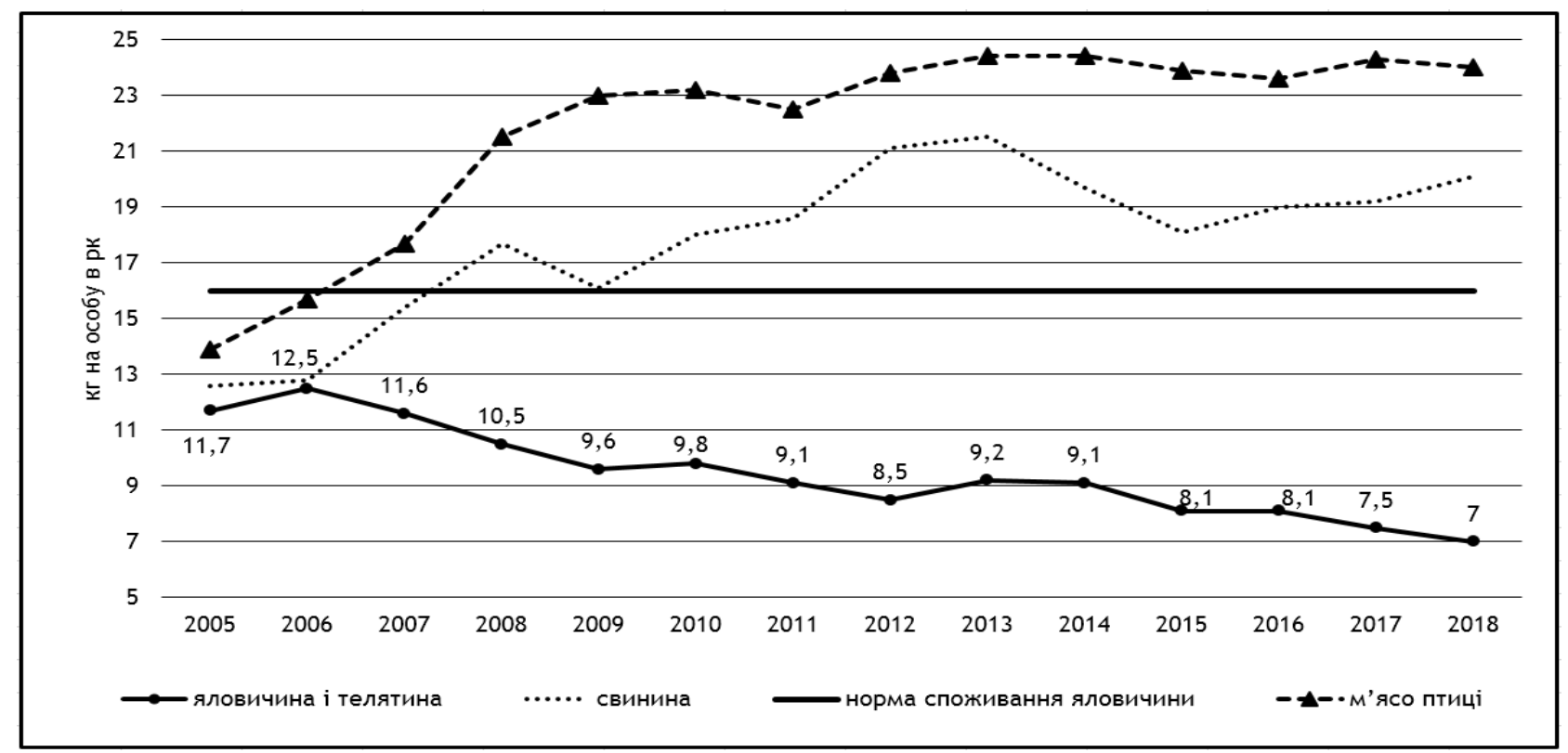

Рис. 3. Споживання різних видів м'яса в Україні та рекомендована норма споживання яловичини

Джерело: 2005-2018 рр., 2018 р. - прогноз, згідно з балансами Meat-Inform [1].

3 аналізу причин низького рівня споживання яловичини та його спадного тренду серед таких - історично сформована низька культура споживання м'яса яловичини, особливо свіжого, за винятком невеликого прошарку населення переважно з високими доходами. Традиційно значну частку виробленої яловичини (до 70\%), навіть у роки розквіту галузі та високого попиту на неї, споживали у вигляді глибоко перероблених м'ясних виробів. Це спостерігається й нині (75\% у 2018 р.), хоча глобалізаційні тренди мають місце і в Україні (правильне харчу-

вання з обов'язковою присутністю в раціоні свіжої яловичини). Проте більшість пропонованої свіжої молочної яловичини нижчої якості, ніж у країнах, де ії активно споживають. Ціни ж на високоякісну свіжу яловичину для вживання в непереробленому виді залишаються високими [16, с. 33].

Як основний обмежувач споживання яловичини слід вказати низькі доходи українців і відповідно їі малодоступність для більшості з них. При цьому ціни на яловичину в роздрібній мережі найвищі порівняно з іншими видами м'яса (рис. 4).

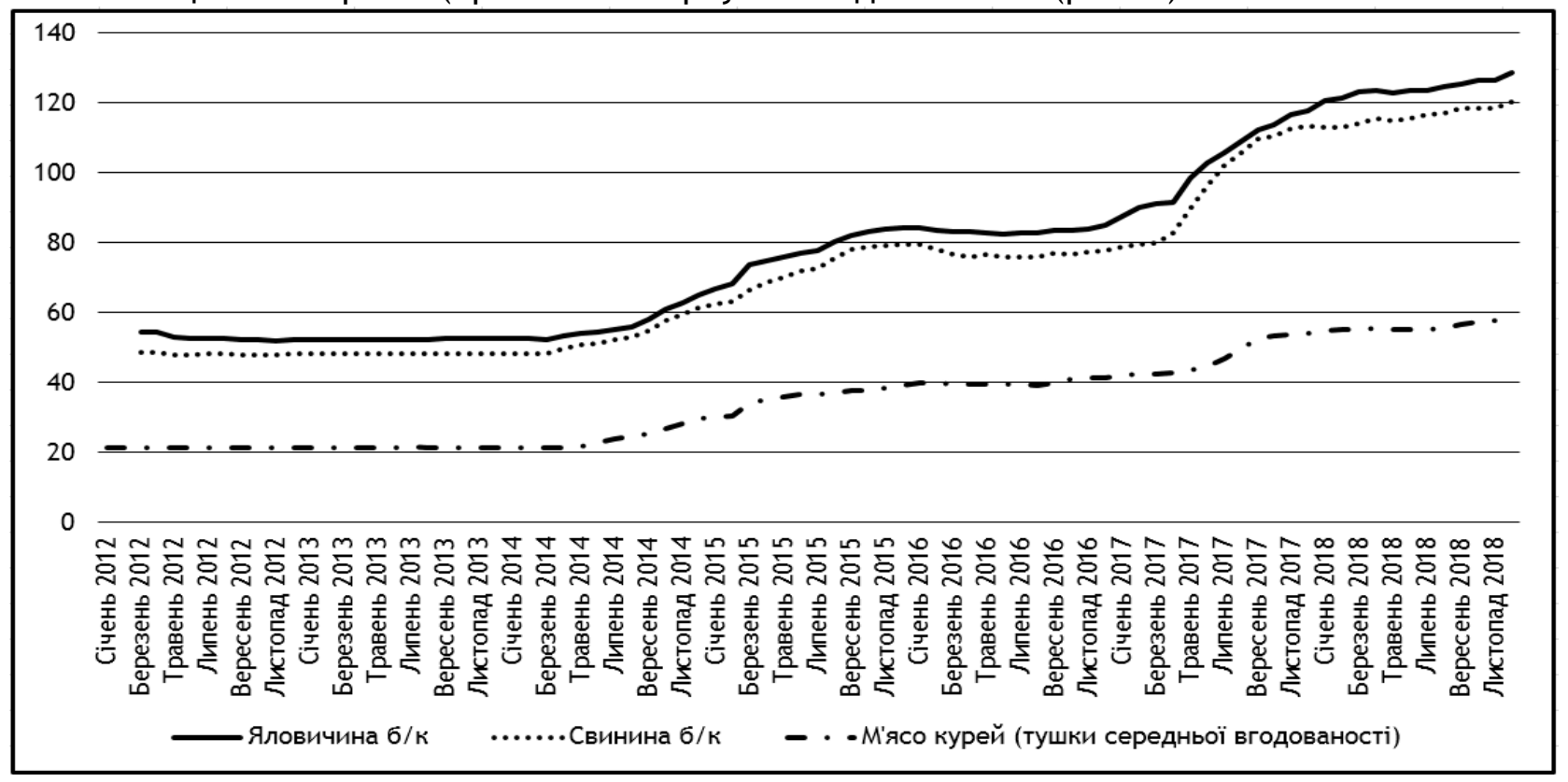

Рис. 4. Помісячні роздрібні ціни на яловичину, свинину та курятину

Джерело: Складено за даними [12]. 
Враховуючи смакові вподобання українців, які поки що не на користь яловичини, а також рівень доходів, очевидний висновок, за яким на сьогодні яловичина не може конкурувати із значно дешевшою курятиною та свининою. Це підтверджують і розрахунки коефіцієнтів еластичності за доходами по різних видах м'яса з використанням моделі AIDS (The Almost Ideal Demand System) ${ }^{2}$, які засвідчили, що нееластичним $\in$ м'ясо курятини (коефіцієнт 0,08), тоді як еластичними, навпаки, свинина та яловичина (коефіцієнти 1,12 та 1,91). Причому яловичина має найвищий показник, тобто іï споживання найбільшою мірою залежить від доходів. Водночас курятину купуватимуть незалежно від ціни, оскільки вона зайняла нішу основного м'ясного продукту в раціоні пересічного українця. Індекс цін на м'ясо, розрахований аналітиками Продовольчої та сільськогосподарської організації ООН (ФАО), свід- чить про подорожчання усіх видів тваринного білка та відповідно посилення світових ринків м'яса, в тому числі й ринку яловичини $[7,2]$. Зростання світових цін впливатиме на внутрішні ціни, які намагатимуться корелювати з ними.

Між доходами і споживанням м'яса яловичини існує залежність (рис. 5). Так, зростання доходів зумовлює зростання споживання яловичини, особливо у міських жителів. Це загальносвітовий тренд, за якого урбанізація означає вищу якість життя, однією з основних складових якого $\epsilon$ підвищення рівня харчування, зокрема й покращення раціону за рахунок дорожчих білків тваринного походження. Можна припустити, що економічний розвиток держави сприятиме збільшенню споживання яловичини, особливо у містах. У разі збільшення доходів прошарок населення, яке купуватиме яловичину, зростатиме.

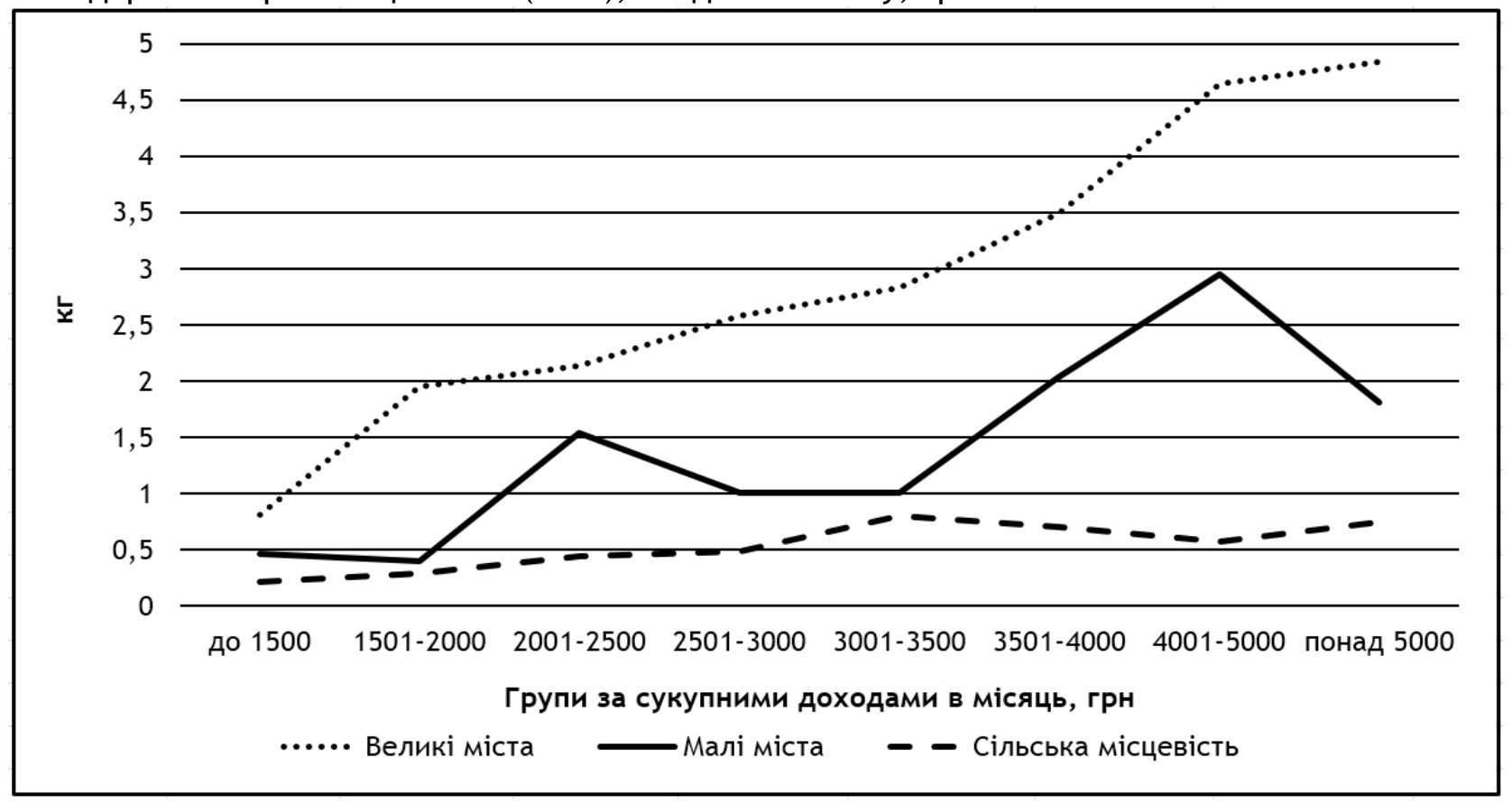

Рис. 5. Залежність споживання яловичини і телятини (свіжа, охолоджена, заморожена) від сукупних доходів, 2018 р.

Джерело: Складено за даними Державної служби статистики України.

Упродовж останніх п'яти років інтерес до української яловичини на світовому ринку суттєво зріс, що підтверджується обсягами поставок на міжнародні ринки. Безперспективність розвитку внутрішнього ринку яловичини, який найближчим часом не подолає конкуренцію 3 курятиною та свининою, змушує виробників змінити свій вектор че-

\footnotetext{
2 Розраховано в Національному науковому центрі «|нститут аграрної економіки» за [15].
}

рез попит на продукцію від сторони зовнішнього споживача. Країни Азії та Близького Сходу найбільше зацікавлені в українській яловичині та готові закуповувати великі обсяги халяльного продукту. Наразі їх основними імпортерами виступають Бразилія, Австралія, Індія, США, Нова Зеландія та Аргентина. Перевага України тут очевидна - насамперед географічна близькість до цих країн порівняно з основними експортерами, а також сприятливі погодні умови, наявність 
вітчизняних м'ясних порід худоби, відносно дешева праця та корми. Проблемою при експорті слід зазначити складні поки що для України вимоги до пакування яловичини, зокрема у світі потребують вакуумований витриманий стейк, охолоджені відрізи, субпродукти. При цьому в Україні пропонують живих бичків, заморожені півтуші та ковбаси. Це пов'язано з відсутністю в українських підприємствах таких обсягів переробки, які 6 дозволили завантажити контейнер за добу. Тому продукція заморожується для накопичення партії. Асоціація тваринників України наголошує і на відсутності достатньої кількості забійних цехів для переробки яловичини, тим паче спеціалізованих халяльних цехів для виробництва яловичини на експорт до Близького Сходу [14]. Звідси набув поширення експорт худоби живцем. У 2017 р. було експортовано рекордну іï кількість худоби - 88111 голів на суму $37,8 \mathrm{Mлн}$ доларів США, у 2018 р. чисельність експортованої худоби зменшилася на 19,8\%, проте іï вартість зросла до 39,3 млн дол. США, або на 4\%. Український живець користується шаленим попитом на зовнішньому ринку, проте для України це означає нижчу додану вартість порівняно з тим, якби експортувалося м'ясо чи субпродукти з нього. За прогнозами ФАО, споживання м'яса всіх видів у країнах Близького Сходу та Азії зростатиме до 2050 р., що для України означатиме сигнал для стабільного попиту на яловичину, a, отже, й поштовх для розвитку вітчизняного м'ясного скотарства.

Найближчим до України $\epsilon$ ринок $€ C$, де яловичина залишається єдиним видом м'яса, стосовно якого існує дефіцит і який лише збільшується. Втім, виділені Україні щорічні квоти у розмірі 12 тис. тонн яловичини не використовуються внаслідок невідповідності вимогам ЄC у сфері контролю якості та безпечності харчових продуктів і складності процедури отримання ліцензії на експорт до ЄС.

Особливості попиту та пропозиції на ринку яловичини (у перерахунку на м'ясо) відображаються у структурі іï експорту й імпорту (рис. 6, 7). У цілому обсяги експорту (у перерахунку на м'ясо) зросли за останні п'ять років від 30,7 до 65,4 тис. тонн, або у 2,1 раза. Зростання експорту відбуватиметься й у майбутньому, що стимулюватиме нарощування поголів'я ВРX у спеціалізованих господарствах.

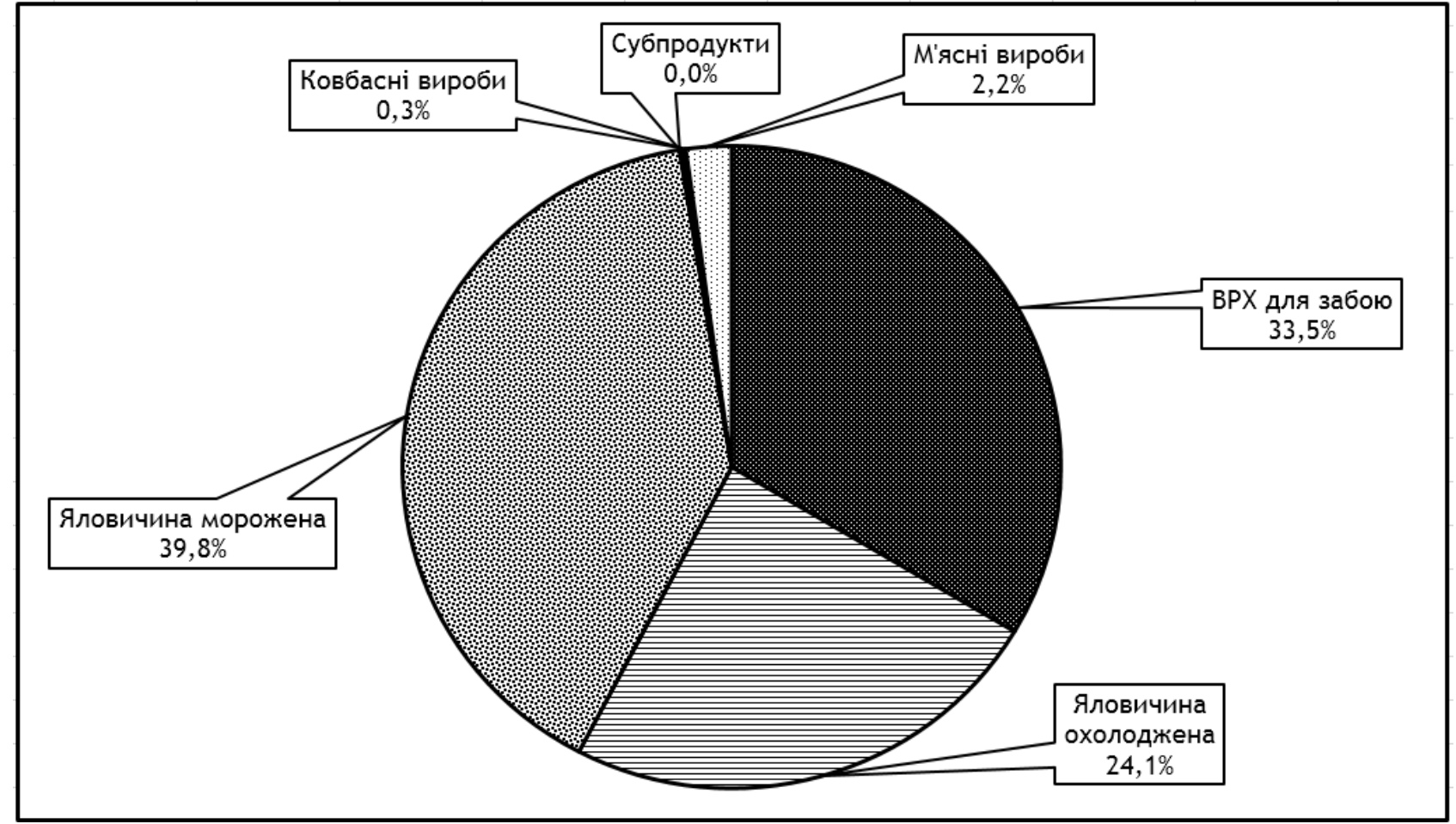

Рис. 6. Структура експорту яловичини за видами з України (у перерахунку на м'ясо), 2018 р.

Джерело: Розраховано авторами за даними Державної служби статистики України.

Низька купівельна спроможність українців та відповідна культура споживання яловичини відображається на структурі імпор- ту, де понад 79\% становлять субпродукти, які завозяться переважно з країн ЄС. 


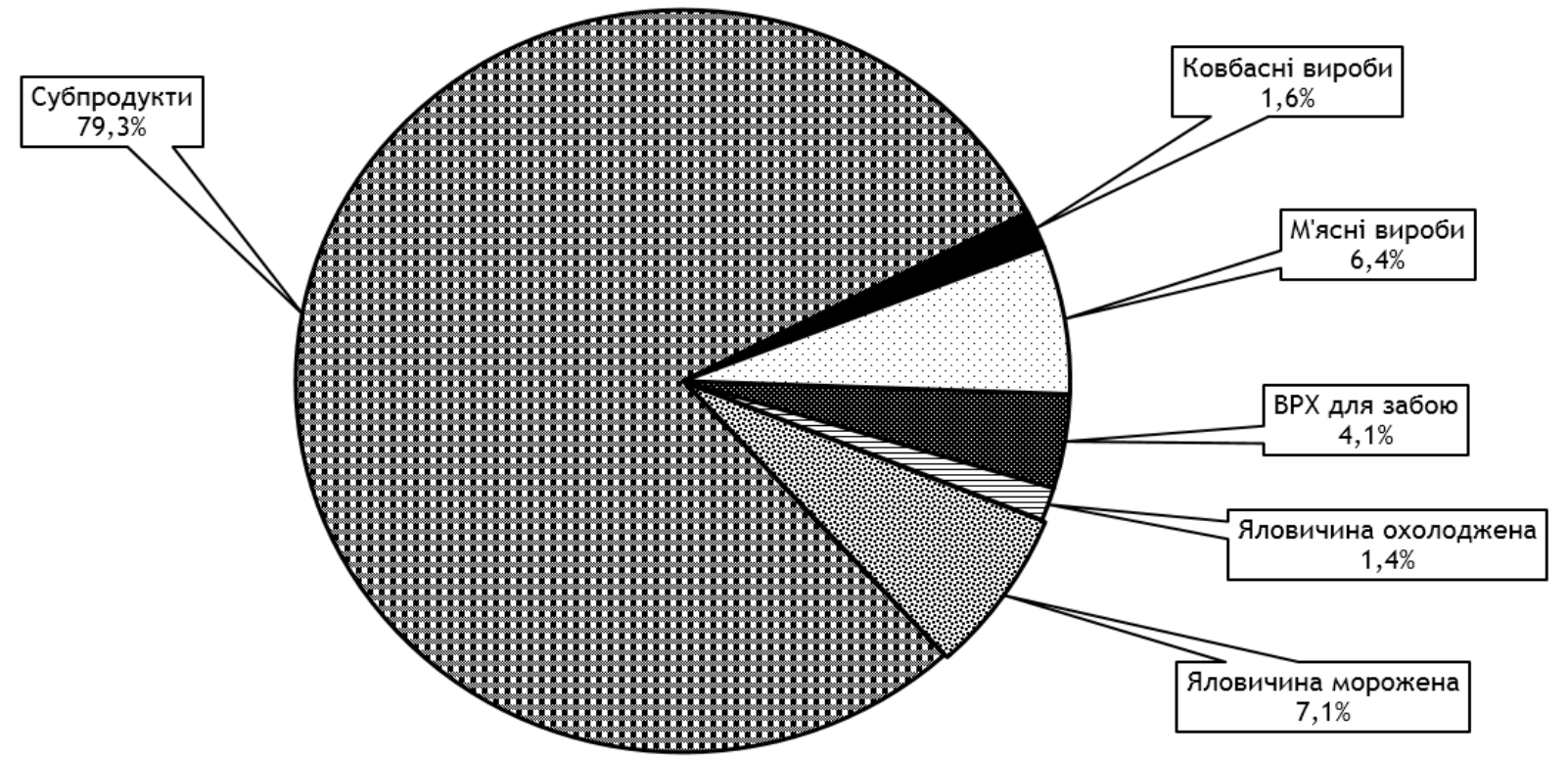

Рис. 7. Структура імпорту яловичини за видами в Україну (у перерахунку на м'ясо), $2018 \mathrm{p}$.

Джерело: Розраховано авторами за даними Державної служби статистики України.

Висновки. Виробництво яловичини, як $\mathrm{i}$ поголів'я ВPX, за останні 30 років перманентно скорочується, тоді як у світі загалом відбується зворотний процес. Найбільший спад відзначено за період 1990-2000 рр., коли було втрачено 62\% поголів'я ВРX переважно у сільськогосподарських підприємствах, яке неможливо наростити швидко навіть за сприятливих умов. Особливістю перехідного періоду стало виробництво яловичини з 1997 р. і понині у приватному секторі, частка якого у загальному виробництві за останні 10 років стабільно перевершує 70\%. Різко змінити такий тренд, враховуючи специфіку галузі, не вдасться, а більшість м'ясної сировини на ринок потраплятиме із селянських подвір'їв.

На переробні підприємства надходить невелика частка реалізованої яловичини (до 20\%). Решта продукції обертається поза організованим ринком, породжуючи різноманітні тіньові схеми. До того ж, наявність великої кількості одноосібників (до $1 \mathrm{Mлн}$ господарств) практично унеможливлює простежити рух яловичини від виробника до споживача.

М'ясне скотарство, як окрема галузь, знаходиться лише на початковому етапі свого розвитку, адже частка м'ясних порід ВРX у сільськогосподарських підприємствах становить лише 5\% від усього поголів'я худоби.
У населення ця частка ще менша. Звідси, вироблена яловичина являє собою відгодівельний молодняк зі шлейфу молочних корів та молочні корови і бички від населення.

Виробництво яловичини, згідно з даними статистики, хронічно збиткове, за винятком 2017 р., коли вперше закупівельна ціна піднялася настільки, що забезпечила прибутковість. Такий ріст цін зумовлений висхідним світовим трендом, що відразу позначилося на внутрішньому ринку.

Споживання яловичини в Україні щорічно зменшується, із показником 44\% від встановленої норми. Основною причиною залишається низька культура споживання цього виду м'яса, особливо у свіжому вигляді, та висока ціна. Яловичина має найбільш слабкі позиції серед основних видів м'яса, поступаючись перед свининою і курятиною, що підтверджують розраховані коефіцієнти еластичності. Зростання доходів стане поштовхом до збільшення споживання яловичини.

Попит на українську яловичину на міжнародному ринку зумовлюється, насамперед, географічною близькістю до країн, в яких зростає рівень споживання та існує їі дефіцит. Дотримання вимог імпортерів до продукції стимулюватиме вітчизняних виробників до розвитку галузі. 


\section{Список бібліографічних посилань}

1. Головний м'ясний портал України Meat Inform. URL : https://meat-inform.com/.

2. Індекс цін м'яса на світовому ринку : суцільне подорожчання. URL : https://meat-inform.com/novyny-pro-miaso/ indeks-tsin-m-iasa-na-svitovomu-rynku-sutsilne-podorozhchannia.html.

3. Кернасюк Ю. В. Ринок яловичини: нові перспективи. Агробізнес сьогодні. 2017. № 24 (367). С. 12-16.

4. Микитюк В. М. Відродження галузі скотарства в умовах ринкових трансформацій : монографія. Житомир : Видво «Житомирський національний агроекологічний університет», 2012. 508 c.

5. Місюк М. В. Ринок продукції скотарства : монографія. Київ : ННЦ IAE, 2012. 330 с.

6. Очікувані показники собівартості продукції, їі дохідності та рентабельності в сільськогосподарських підприємствах України у 2018 році: методика і розрахунки (грудень 2018 року) / [Лупенко Ю. О., Месель-Веселяк В. Я., Грищенко О. Ю., Волосюк Ю. В.] ; за ред. Ю. О. Лупенка, В. Я. МесельВеселяка. Київ : ННЦ «ІАЕ», 2018. 68 с.

7. Панкратов А. Закінчується рік: що $\epsilon$ i що буде на ринку м'яса. Грудень 15, 2018. URL : https://meat-inform.com/ analityka-miasnoho-rynku/zakinchuietsia-rik-shcho-ie-i-shcho-budena-rynku-m-iasa.html.

8. Практичний довідник експортера м'ясної продукції / Бурка А., Гонтар В., Ярмак А. та ін. FAO, 2017. 204 с.

9. Про затвердження наборів продуктів харчування, наборів непродовольчих товарів та наборів послуг для основних соціальних і демографічних груп населення : Постанова Кабінету Міністрів України № 780 від 11 жовтня 2016 року. URL : https://zakon.rada.gov.ua/laws/show/780-2016-\%D0\%BF.

10. Розвиток м'ясопродуктового підкомплексу України : монографія / [М. В. Гладій, П. Т. Саблук, Н. Г. Копитець та ін.] ; за ред. М. В. Гладія. Київ : ННЦ IAE, 2012. 354 с.

11. Свиноус І. В., Туржанський В. А. Реалізація продукції великої рогатої худоби господарствами приватного сектору через систему торгово-посередницьких структур. Економіка АПК. 2006. № 10. С. 82-86.

12. Ціновий моніторинг сільськогосподарської продукції та продуктів її переробки 2012-2018 рр. / Ю. О. Лупенко, О. М. Шпичак, О. В. Боднар та ін. Київ : ННЦ «ІAE», 2018. 60 с.

13. Як довго в Україні може дорожчати м'ясо: ціни та прогнози. URL : https://shuvar.com/news/1387/Yak-dovho-/ v-Ukrayini-mozhe-dorozhchaty-myaso:-tsiny-ta-prohnozy.

14. Яловичина, живець ВРX та шкури тварин $є$ дуже бажаною продукцією для українських імпортерів. URL : https://usba.com.ua/alovicina-zivec-vrh-ta-skuri-tvarin-eduze-bazanou-produkcieu-dla-ukrainskih-importeriv.

15. Henningsen Arne Demand analysis with the "Almost Ideal Demand System" in R: Package micEconAids Department of Food and Resource Economics, University of Copenhagen, 1980. $36 \mathrm{p}$.

16. Yarmak A., Svyatkivska E., Prikhodko D. Ukraine Meat sector review. Rome: FAO, 2014. 146 p.

\section{References}

1. Holovnyi miasnyi portal Ukrainy Meat Inform [The main meat portal of Ukraine Meat Inform]. Retrieved from: https://meat-inform.com [In Ukrainian].

2. Indeks tsin miasa na svitovomu rynku: sutsilne podorozhchannia [The index of meat prices on the world market: a solid increase in prices]. (2019). Meat Inform. Retrieved from: https: / /meat-inform.com/novyny-pro-miaso/indeks-tsin-m-iasana-svitovomu-rynku-sutsilne-podorozhchannia.html [In Ukrainian].

3. Kernasiuk, Yu.V. (2017). Rynok yalovychyny: novi perspektyvy [Beef market: new perspectives]. Ahrobiznes sohodni, 24 (367), pp. 12-16 [In Ukrainian].

4. Mykytiuk, V.M. (2012). Vidrodzhennia haluzi skotarstva $v$ umovakh rynkovykh transformatsii: monohrafiia [Revival of cattle breeding under the conditions of market transformations: monograph]. Zhytomyr: Vyd-vo "Zhytomyrskyi natsionalnyi ahroekolohichnyi universytet" [In Ukrainian].

5. Misiuk, M.V. (2012). Rynok produktsii skotarstva: monohrafiia [Livestock market: monograph]. Kyiv: NSC IAE [In Ukrainian].

6. Lupenko, Yu.O., Mesel-Veseliak, V.Ya., Hryshchenko, O.Yu., et al. (2018). Ochikuvani pokaznyky sobivartosti produktsii, yii dokhidnosti ta rentabelnosti $v$ silskohospodarskykh pidpryiemstvakh Ukrainy u 2018 rotsi: metodyka i rozrakhunky [Expected indicators of the cost of production, its revenue and profitability in the agricultural enterprises of Ukraine in 2018: methods and calculations]. Yu.O. Lupenko, V.Ya. MeselVeseliak (Eds.). Kyiv: NSC "IAE" [In Ukrainian].

7. Pankratov, A. (2018). Zakinchuietsia rik: shcho ye i shcho bude na rynku miasa [The year has been coming to the end: what are and what will be on the meat market]. Retrieved from: https://meat-inform.com/analityka-miasnoho-rynku/ zakinchuietsia-rik-shcho-ie-i-shcho-bude-na-rynku-m-iasa.html [In Ukrainian].

8. Burka, A., Hontar, V., Yarmak, A., et al. (2017). Praktychnyi dovidnyk eksportera miasnoi produktsii [Practical guide for meat products exporter]. FAO [In Ukrainian].

9. Pro zatverdzhennia naboriv produktiv kharchuvannia, naboriv neprodovolchykh tovariv ta naboriv posluh dlia osnovnykh sotsialnykh i demohrafichnykh hrup naselennia: Postanova Kabinetu Ministriv Ukrainy № 780 vid 11 zhovtnia 2016 roku [On approving the sets of food and non-food items and sets of services for main social and demographic groups: Resolution of the Cabinet of Ministers of Ukraine dated 11.10.2016, No. 780]. Zakon Rada. Retrieved from: https://zakon.rada.gov.ua/laws/ show $/ 780-2016-\%$ D0\%BF [In Ukrainian]

10. Hladii, M.V., Sabluk, P.T., Kopytets, N.H., et al. (2012). Rozvytok miasoproduktovoho pidkompleksu Ukrainy: monohrafiia [Development of meat subcomplex of Ukraine: monograph]. M.V. Hladii (Ed.). Kyiv: NSC IAE [In Ukrainian].

11. Svynous, I.V. \& Turzhanskyi, V.A. (2006). Realizatsiia produktsii velykoi rohatoi khudoby hospodarstvamy pryvatnoho sektoru cherez systemu torhovo-poserednytskykh struktur [Sale of cattle products by private sector farms through the system of trade and intermediary structures]. Ekonomika APK, 10, pp. 82-86 [In Ukrainian].

12. Lupenko, Yu.O., Shpychak, O.M., Bodnar, O.V., et al. (2018). Tsinovyi monitorynh silskohospodarskoi produktsii ta produktiv yii pererobky 2012-2018 r.r. [Price monitoring of agricultural and processed products in 2012-2018]. Kyiv: NSC “IAE" [In Ukrainian].

13. Yak dovho $v$ Ukraini mozhe dorozhchaty miaso: tsiny ta prohnozy [How long will have been the meat price growing up in Ukraine: prices and forecasts]. (2017). Informatsiinyi servis "Shuvar info". Retrieved from: https://shuvar.com/news/ 1387/Yak-dovho-v-Ukrayini-mozhe-dorozhchaty-myaso:-tsinyta-prohnozy [In Ukrainian].

14. Yalovychyna, zhyvets VRKh ta shkury tvaryn ye duzhe bazhanoiu produktsiieiu dlia ukrainskykh importeriv [Beef, live cattle and animal skins are very desirable products for Ukrainian importers.]. (2017). Asotsiatsiia tvarynnykiv Ukrainy. Retrieved from: https: / /usba.com.ua/alovicina-zivec-vrh-ta-skuritvarin-e-duze-bazanou-produkcieu-dla-ukrainskih-importeriv [In Ukrainian]. 
15. Henningsen, A. (1980). Demand analysis with the "Almost Ideal Demand System" in R: Package micEconAids. Department of Food and Resource Economics, University of Copenhagen [In English].

16. Yarmak, A., Svyatkivska, E., \& Prikhodko, D. (2014). Ukraine meat sector review. Rome: FAO [In English].

\section{Kozak O.A., Hryshchenko O.Yu. Demand and supply features in the beef market}

The purpose of the article is to carry out a comprehensive analysis of the demand and supply features in the Ukrainian beef market with definition of the major factors influencing further development of this segment.

Research methods. During the research, the following methods were used: abstract and logical for making conclusions; monographic for detail description of the beef market activity; comparative analysis and time series for comparing indicators and identifying trends of their changes over time; statistical for supply and demand analysis in the beef market; graphic for identifying and illustrating trends of studied economic phenomena; economic and mathematical methods for determining economic indicators that affect the beef supply and demand.

Research results. The current state of the beef market in Ukraine was analysed and the main problems of its development were identified from a perspective of both a producer and a consumer. Formation of supply takes place in conditions of low competitiveness of products due to a combination of factors: unprofitability of the industry, deformed market structure, significant lack of meat cattle husbandry as a separate segment. The peculiarities of demand are low beef consumption culture, limited purchasing power of the population, high price of beef compared to chicken and pork. The impetus for the industry development will be the export growth, which has been intensified over the past 5 years.

Elements of scientific novelty. Analytical evaluations and definitions of influence of the main factors on the formation of supply and demand in the beef market of Ukraine were further developed.

Practical significance. The results of the study will be useful for producers and consumers of beef, as well as stakeholders of the beef value chain. Reasonable conclusions could serve as a guide for officials in the development of a long-term policy for the beef market development in Ukraine. Tabl.: 2. Figs.: 7. Refs.: 16.

Keywords: demand; supply; beef market; meat cattle husbandry; export; import; Ukraine.

Kozak Olga Anatoliivna - candidate of economic sciences, senior research fellow, leading research fellow of the department of economics of agricultural production and international integration, National Scientific Centre "Institute of Agrarian Economics" (10, Heroiv Oborony st., Kyiv)

E-mail: olya.kozak@gmail.com

ORCID iD https://orcid.org/0000-0002-2197-3456

Hryshchenko Olena Yuriivna - head of the sector of research informational support, National Scientific Centre "Institute of Agrarian Economics" (10, Heroiv Oborony st., Kyiv)

E-mail: lena@iae.gov.ua

\section{Козак О.А., Грищенко Е.Ю. Особенности формирования спроса и предложения на рынке говядинь}

Цель статьи - осуществить комплексный анализ особенностей формирования спроса и предложения на рынке говядины Украины.

Методика исследования. В процессе исследования использованы методы: абстрактно-логический - для формулировки выводов; монографический - при детализации функционирования рынка говядины; сравнительного анализа и рядов динамики - для сравнения показателей и выявления тенденций их изменения во времени; статистический - при проведении анализа спроса и предложения на рынке говядины; графический - для выявления и иллюстрации тенденций исследуемых экономических явлений; экономикоматематические методы - при определении экономических показателей, влияющих на спрос и предложение говядины.

Результаты исследования. Проанализировано современное состояние рынка говядины в Украине и определены основные проблемы его развития с позиции как производителя, так и потребителя. Выяснены факторы, которые в наибольшей мере влияют на формирование спроса и предложения говядины.

Элементы научной новизны. Получили дальнейшее развитие аналитические оценки и определения влияния основных факторов на формирование спроса и предложения на рынке говядины Украины.

Практическая значимость. Результаты исследования будут полезными для производителей и потребителей говядины, а также заинтересованных сторон продовольственной цепи этой продукции. Обоснованные выводы могут служить ориентиром для чиновников при разработке долгосрочной политики развития рынка говядины в Украине. Табл.: 2. Илл.: 7. Библиогр.: 16.

Ключевые слова: спрос; предложение; рынок говядины; мясное скотоводство; экспорт; импорт; Украина.

Козак Ольга Анатольевна - кандидат экономических наук, старший научный сотрудник, ведущий научный сотрудник отдела экономики аграрного производства и международной интеграции, Национальный научный центр «Институт аграрной экономики» (г. Киев, ул. Героев Обороны, 10)

E-mail: olya.kozak@gmail.com

ORCID iD https://orcid.org/0000-0002-2197-3456

Грищенко Елена Юрьевна - заведующая сектором информационного обеспечения исследований, Национальный научный центр «Институт аграрной экономики» (г. Киев, ул. Героев Обороны, 10)

E-mail: lena@iae.kiev.ua

Стаття надійшла до редакції 07.06.2019 р.

Фахове рецензування: 05.07.2019 р.

Бібліографічний опис для цитування:

Козак О. А., Грищенко О. Ю. Особливості формування попиту та пропозиції на ринку яловичини. Економіка АПК. 2019. № 7. С. 21 - 31. 